\title{
Vegetation responses to climate extremes recorded by remotely sensed atmospheric formaldehyde
}

\author{
Catherine Morfopoulos ${ }^{1,2}$ (1) | Jean-François Müller ${ }^{3}$ | Trissevgeni Stavrakou ${ }^{3}$ | \\ Maite Bauwens $^{3}$ | Isabelle De Smedt ${ }^{3}$ | Pierre Friedlingstein ${ }^{4}$ | lain Colin Prentice ${ }^{1,5,6}$ | \\ Pierre Regnier $^{2}$
}

${ }^{1}$ Department of Life Sciences, Imperial College London, Silwood Park, UK

${ }^{2}$ Department of Geoscience, Environment \& Society-BGEOSYS, Université Libre de Bruxelles, Brussels, Belgium

${ }^{3}$ Royal Belgian Institute for Space Aeronomy, Brussels, Belgium

${ }^{4}$ College of Engineering, Mathematics and Physical Sciences, University of Exeter, Exeter, UK

${ }^{5}$ Ministry of Education Key Laboratory for Earth System Modeling, Department of Earth System Science, Tsinghua University, Beijing, China

${ }^{6}$ Department of Biological Sciences, Macquarie University, North Ryde, New South Wales, Australia

\section{Correspondence}

Catherine Morfopoulos, Department of Life Sciences, Imperial College London, Silwood Park, UK.

Email: c.morfopoulos@imperial.ac.uk

Funding information

European Research Council, Grant/Award Number: 787203; Belgian Federal Science Policy Office; Belgian Research Action

\begin{abstract}
Accurate monitoring of vegetation stress is required for better modelling and forecasting of primary production, in a world where heatwaves and droughts are expected to become increasingly prevalent. Variability in formaldehyde $(\mathrm{HCHO})$ concentrations in the troposphere is dominated by local emissions of short-lived biogenic (BVOC) and pyrogenic volatile organic compounds. BVOCs are emitted by plants in a rapid protective response to abiotic stress, mediated by the energetic status of leaves (the excess of reducing power when photosynthetic light and dark reactions are decoupled, as occurs when stomata close in response to water stress). Emissions also increase exponentially with leaf temperature. New analytical methods for the detection of spatiotemporally contiguous extremes in remote-sensing data are applied here to satellite-derived atmospheric $\mathrm{HCHO}$ columns. BVOC emissions are shown to play a central role in the formation of the largest positive $\mathrm{HCHO}$ anomalies. Although vegetation stress can be captured by various remotely sensed quantities, spaceborne $\mathrm{HCHO}$ emerges as the most consistent recorder of vegetation responses to the largest climate extremes, especially in forested regions.
\end{abstract}

\section{KEYWORDS}

atmospheric remote sensing, climate extremes, formaldehyde, photosynthesis, stress, vegetation, volatile organic compounds

\section{1 | INTRODUCTION}

Vegetation stress is manifested in reduced gross primary production (GPP), but direct, large-scale measurements of GPP do not exist. Satellite-based products such as the normalized difference vegetation index (NDVI) and derived quantities including fractional absorbed photosynthetically active radiation (fAPAR) and leaf area index (LAI) have long been used to monitor vegetation activity, but these indices are all based on visible and near-infrared reflectance and primarily indicate changes in vegetation cover and chlorophyll content, not GPP. Additionally, under condition of abiotic stress, other photosynthetic pigments, that is, xanthophyll pigments that trigger non-photochemical quenching (NPQ), come into play in partitioning light use efficiency (Esteban et al., 2015). The recent development of remotely sensed solar-induced passive fluorescence (SIF) products have provided additional insights on GPP because a

This is an open access article under the terms of the Creative Commons Attribution NonCommercial License, which permits use, distribution and reproduction in any medium, provided the original work is properly cited and is not used for commercial purposes.

(C) 2021 The Authors. Global Change Biology published by John Wiley \& Sons Ltd. 
fraction of the energy absorbed by chlorophyll is dissipated by this pathway. However, although SIF and photosynthesis are usually positively correlated under normal conditions, very little is known about their relationship under heat- or water-stressed conditions. Here again, additional information on the xanthophyll cycle regulatory mechanisms would be necessary to better constrain the relationship between SIF and GPP at larger scales (Alonso et al., 2017; Chen et al., 2021; Frankenberg \& Berry, 2017). Moreover, the available time series of SIF are relatively short.

Monitoring vegetation responses to climate extremes more generally is handicapped by the relatively short time periods of observations, making it difficult to achieve statistical significance when the number of events is small. To overcome this difficulty, previous studies have developed analytical approaches allowing the detection of spatiotemporally contiguous extremes (Lloyd-Hughes, 2012; Reichstein et al., 2013; Zscheischler et al., 2013, 2014). These studies have been carried out using remotely sensed NDVI, fAPAR or LAI. Their general conclusion has been that large, contiguous negative anomalies in vegetation cover occur mostly in savannas and grasslands, and are mainly due to drought. These indicators have proved less useful in recording responses to climate extremes in forests, therefore we propose to investigate the extent to which formaldehyde $(\mathrm{HCHO})$ can be used to infer vegetation stress at regional to global scales.

Photo-oxidation of hydrocarbons leads to the production of $\mathrm{HCHO}$ in the atmosphere. Methane oxidation is the largest source of $\mathrm{HCHO}$, but methane-derived $\mathrm{HCHO}$ is diffused across the globe because methane oxidation is a slow (decadal) process. $\mathrm{HCHO}$ column variability over land is, therefore, mainly due to local emissions of more reactive non-methane volatile organic compound (NMVOC) emissions (Brasseur et al., 1999; Palmer et al., 2003; Stavrakou et al., 2009). Atmospheric NMVOCs are dominated by biogenic volatile organic compounds (BVOCs), accounting for about $90 \%$ of the emissions (Guenther et al., 1995). These are supplemented intermittently by emissions of pyrogenic volatile organic compounds (PVOCs) from biomass burning. BVOCs produced by plants (and especially by many tree species) are involved in many functions including growth, reproduction, protection, signalling and defence (Peñuelas \& Staudt, 2010). Isoprene constitutes the largest part of BVOC emitted to the atmosphere, accounting for about half of the total emissions, which amount to $700-1000 \mathrm{Tg} \mathrm{C}^{-1}$ (Guenther et al., 2012). BVOC production by plants is usually linked to photosynthetic carbon assimilation. However, decoupling between isoprene emission and carbon assimilation occurs under abiotic stresses including high temperature, high radiation and extreme water stress. Under these conditions, the supply of photosynthetically generated reducing power can exceed the demands of carbon fixation and photorespiration (Morfopoulos et al., 2014; Peñuelas et al., 2013). In such situations, isoprene emissions are enhanced while productivity declines (Brilli et al., 2007; Fang et al., 1996; Sharkey \& Loreto, 1993; Tingey et al., 1981).

Plants' ability to rapidly increase isoprene production while photosynthesis is restricted has proven benefits, as isoprene appears to protect the photosynthetic apparatus from both thermal and oxidative stress. The detailed mechanisms of this protective effect are debated, but there is evidence that isoprene stabilizes lipid membranes at high temperatures, and quenches reactive oxygen species that are produced in leaves under heat stress (Sharkey \& Monson, 2017). Monoterpene emissions, which account for $10 \%-20 \%$ of BVOC emissions, are also enhanced during heat stress (Guenther et al., 2012). Both isoprene and monoterpene emissions respond exponentially to increasing leaf temperature, enhancing the probability of detecting changes in emissions not only under heat-induced stress but also under conditions when stomata close due to drought. Furthermore, some studies suggest that isoprene and monoterpenes emissions are correlated to NPQ through the xanthophyll cycle (Filella et al., 2018; Peñuelas et al., 2013).

Droughts also promote fire activity, and the associated emissions of numerous PVOCs (Andreae, 2019). Although human activities influence fire regimes in many ways, hot and dry conditions are essential to turn small fires into very large ones-especially in tropical moist forests, which are otherwise protected by their high moisture content (Bowman et al., 2011). There are also direct anthropogenic emissions of NMVOCs, but they are of little importance at the global scale. As $\mathrm{HCHO}$ and its precursors' atmospheric lifetimes are short, $\mathrm{HCHO}$ column variability is primarily due to local surface emissions (Palmer et al., 2003). Thus, we expect HCHO columns to be large when vegetation suffers climatic extremes (Figure 1). Smearing effects due to the delay between $\mathrm{VOC}$ emission and HCHO formation occur at spatial scales not exceeding $200-300 \mathrm{~km}$ for isoprene (Marais et al., 2012).

Here, we analyse spatiotemporally contiguous extremes in monthly remotely sensed $\mathrm{HCHO}$ columns. We compare the results with extremes in other vegetation remote-sensing products; with climate data; and with model outputs. We evaluate the roles played by BVOC and PVOC in the main extreme events detected in the $\mathrm{HCHO}$ columns. Finally, we discuss the benefits of using $\mathrm{HCHO}$ columns to track vegetation responses to climate extremes.

\section{2 | MATERIAL AND METHODS}

\section{$2.1 \mathrm{HCHO}$ and BVOC data}

We used monthly remotely sensed $\mathrm{HCHO}$ integrated columns from the Ozone Monitoring Instrument (OMI) spectrometer over 20052016 on a $0.25^{\circ} \times 0.25^{\circ}$ spatial resolution (De Smedt et al., 2018). The $\mathrm{OMI} \mathrm{HCHO}$ tropospheric columns are retrieved using a differential optical absorption spectroscopy algorithm comprising (1) the fit of the slant column and (2) a radiative transfer calculation of the mean light path to transform the slant into a vertical column (the air mass factor). In addition, the tropospheric column is normalized using the remote Pacific Ocean as reference region (background correction). The OMI HCHO slant columns are retrieved in the $328.5-359 \mathrm{~nm}$ interval. Observations with cloud fractions larger than $40 \%$ are filtered out. Daily prior HCHO profiles are obtained from the TM5 model. 


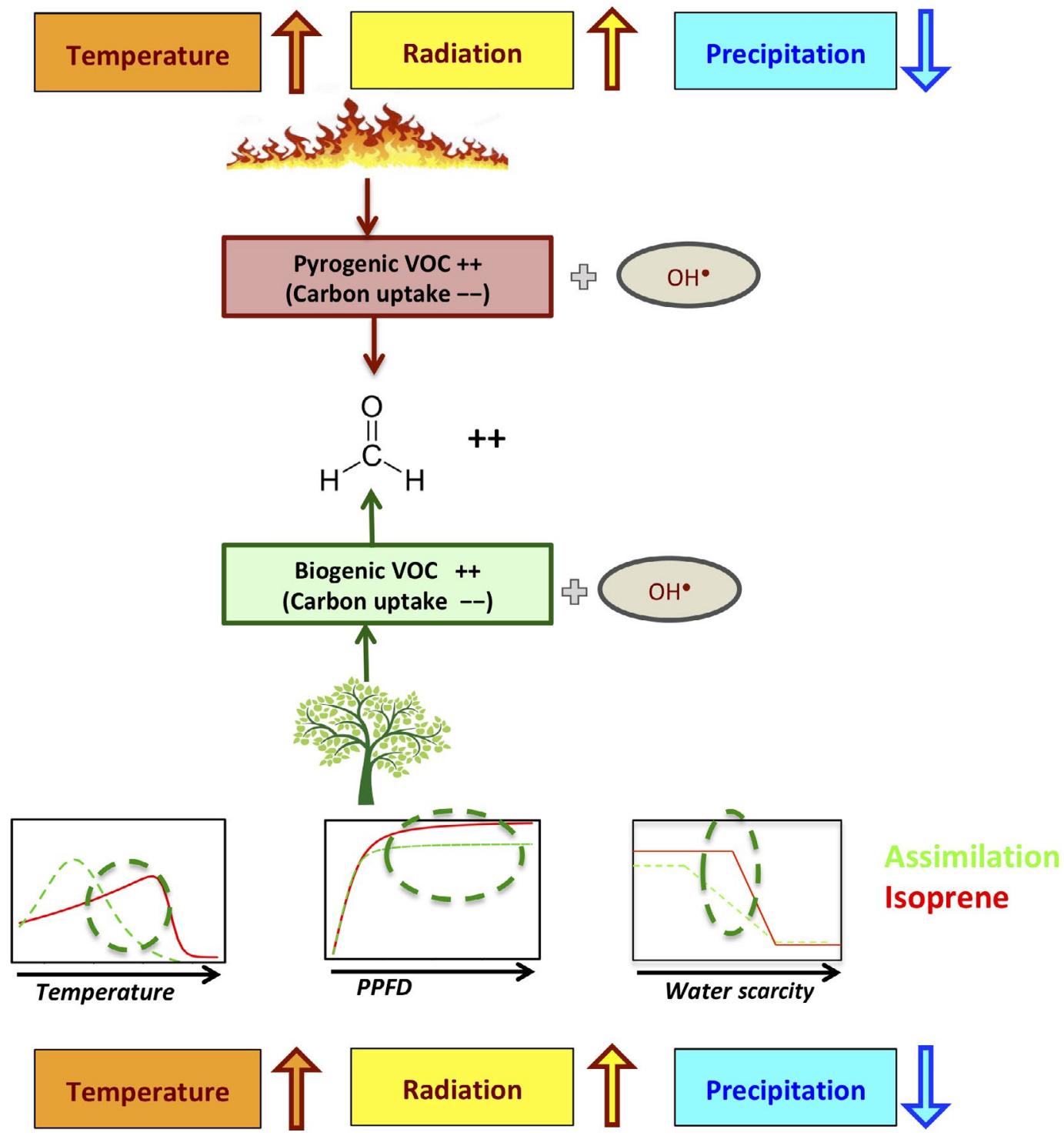

FIGURE 1 Schematic representing processes leading to an increase of atmospheric HCHO. High temperature, radiation and water deficit favour fire activity, which increases PVOC emissions and decreases carbon uptake. These conditions also trigger the BVOC defence mechanism where photosynthetic carbon uptake is reduced while BVOC emissions are enhanced. Increase in both BVOC and PVOC result in an increase of atmospheric $\mathrm{HCHO}$. BVOC, biogenic volatile organic compound; $\mathrm{HCHO}$, formaldehyde; PVOC, pyrogenic volatile organic compound

Total column averaging kernels are provided for each pixel and are taken into account in comparisons with the IMAGES model (see below). The OMI data are available at http://www.qa4ecv.eu.

$B V O C$ emissions were simulated by the Model of Emissions of Gases and Aerosols from Nature version 2.1 (MEGAN2.1; Guenther et al., 2012). MEGAN considers the major processes driving variations in BVOC emissions; each BVOC has an associated standard emission factor, whose geographical distribution is obtained from MEGAN2.1 (https://bai.ess.uci.edu/megan/data-and-code/megan21). Fluxes of $B V O C$ are estimated by multiplying the standard emission factor by functions accounting for how emissions vary with light, temperature, leaf age, soil moisture, $\mathrm{LAI}$ and $\mathrm{CO}_{2}$ concentration. We limited attention to emissions of isoprene, monoterpenes and methanol, which are the main BVOC precursors of $\mathrm{HCHO}$.
Modelled HCHO columns were obtained from the IMAGES model, which calculates the distribution of 172 compounds at $2^{\circ} \times 2.5^{\circ}$ resolution using meteorological fields from the ERA-Interim analysis by the European Centre for Medium-Range Weather Forecasts (Bauwens et al., 2016). Simulations were made for 2005-2016 with a spin-up period of 6 months. Anthropogenic VOC emissions were provided to the model from the EDGAR v4.3.2 global inventory (http://edgar.jrc. ec.europa.eu/overview.php? $v=432$ ). Biomass burning emissions were from GFED4s and BVOC fluxes from MEGAN. The PVOC oxidation mechanism includes an explicit representation of 16 individual compounds; the impact of the remaining PVOCs on $\mathrm{HCHO}$ production is accounted for through an additional, lumped species (Stavrakou et al., 2009). The isoprene oxidation mechanism has been revised to account for recent advances as described in Stavrakou et al. (2018). 


\subsection{Climate data}

For surface air temperature and precipitation, we used monthly climate data from the University of East Anglia's Climate Research Unit CRU TS3.25 at a spatial resolution of $0.5^{\circ} \times 0.5^{\circ}(2005-2016$; Harris et al., 2014). CRU TS data sets are available from the University of East Anglia (http://www.cru.uea.ac.uk/). For net short-wave radiation, we used data from the monthly NCEP/NCAR reanalysis available at a spatial resolution of $1.87^{\circ} \times 1.91^{\circ}(2005-2016)$ at https:// www.esrl.noaa.gov/psd/data/gridded/data.ncep.reanalysis.deriv ed.surfaceflux.html.

Land surface temperature (LST) data were obtained from the global monthly daytime LST product MOD11C3 LST (Collection 6) obtained from the MODIS sensor (https://modis-land.gsfc.nasa. gov/) at $0.05^{\circ} \times 0.05^{\circ}$ resolution, upscaled from daily global data at $1 \mathrm{~km}^{2}$ resolution. This data set has been substantially improved compared to Collection 5 data, especially with regard to cloud contamination effects (Wan, 2014).

\section{3 | Vegetation data}

We used the version of GIMMS3g LAI v1 generated by training the GIMMS3g v1 NDVI with MODIS LAI using an artificial neural network (Zhu et al., 2013). This data set has temporal resolution of 15 day at a $1 / 12^{\circ}$ spatial resolution. We extracted data from 2005 to 2016. GIMMS3g LAI data are available at http://cliveg.bu.edu/modis misr/lai3g-fpar3g.html.

SIF data were obtained from GOME2_F version 26 (V27) retrievals from the GOME-2 instrument (Joiner et al., 2013). This data set provides monthly data with a spatial resolution of $0.5^{\circ} \times 0.5^{\circ}$ for 2007-2016. GOME2 SIF data sets are available at https://avdc.gsfc. nasa.gov/pub/data/satellite/MetOp/GOME_F/.

TRENDY GPP was modelled using the ensemble mean of simulations by the Dynamic Global Vegetation Models (DGVMs) participating in the TRENDY project (Sitch et al., 2008). We used the $\mathrm{S} 3$ series of simulations, where climate, $\mathrm{CO}_{2}$ concentration and land use all vary over time. Models outputs were obtained at a spatial resolution of $1^{\circ} \times 1^{\circ}$ during $2005-2016$. More details about the TRENDY protocol, and the participating DGVMs, can be found at http://dgvm. ceh.ac.uk/node/21/index.html. Raw DGVM output is available from http://www-Iscedods.cea.fr/invsat/RECCAP/.

FLUXCOM GPP is calculated using machine learning to combine GPP flux measurements from FLUXNET eddy covariance towers with remote sensing and meteorological data. Here, we used the RS_METEO-CRUJRA_v1 collection obtained at a spatial resolution of $1^{\circ} \times 1^{\circ}$ for the 2005-2016 period (http://www.fluxcom.org/CFProducts/; Jung et al., 2020; Tramontana et al., 2016).

Biomass burning emissions were obtained from the fourth version of the Global Fire Emissions Database including small fires (GFED4s; van der Werf et al., 2017; www.globalfiredata.org). GFED4s combines satellite information on fire activity and vegetation productivity to estimate gridded monthly burned area and fire emissions. We used monthly fire carbon (C) emissions with a spatial resolution of $0.25^{\circ} \times 0.25^{\circ}$ during $2005-2016$.

\subsection{Extreme detection}

\subsection{1 | Data pre-processing}

All data sets were analysed at a monthly time scale over 2005-2016 with the exception of SIF, as SIF data are available only from 2007. Each data set was rescaled to the same grid as the $\mathrm{OMI} \mathrm{HCHO}$ data set $\left(0.25^{\circ} \times 0.25^{\circ}\right)$ using the First-order Conservative Remapping CDO (remapcon) function. A desert mask, based on MODIS LAI, was applied to all data.

For each data set, we applied the three-step method described by Zscheischler et al. (2013). At each pixel, first the long, linear trend was subtracted, then the mean annual cycle. These two steps permit comparison of absolute anomaly values over time for any given pixel. Then, each time series of absolute anomalies was standardized by its temporal variance, resulting in dimensionless anomalies that can be compared across latitudes or vegetation types.

\subsection{2 | Spatio-temporal localization of extremes}

Based on this pre-processed data set, we defined a global symmetric threshold for extremes ( $q$ ) such that $90 \%$ of standardized anomalies range between $-q$ and $q$ (equivalent to the 5 th and 95th percentiles). Values above $q$ (experiencing a positive extreme above the 95th percentile) were set to 1 ; the rest of the data set was set to 0 . We thus obtained a data cube of binary voxels (elements of the data cube with unique $3 \mathrm{D}$ coordinates longitude $\times$ latitude $\times$ time). A flood-fill algorithm (the function connComp3D from the R package neuroim) was used to connect spatially and temporally connected voxels with value 1 . Two voxels were considered to be connected if one belongs to the 26 neighbours of the other (as we allow for diagonal neighbours). Clusters, thus, identified were ranked by size (number of connected voxels). Figure 2 summarizes this processing chain.

Note that Zscheischler et al. (2013) recommended step 3 in data pre-processing, but did not apply it. This could cause differences between their results and ours (for the detection of extremes in LAI for example) as defining a global threshold for extremes using nonstandardized anomalies can highlight regions of higher variance.

\subsection{Identification of climate extremes concurrent to detected $\mathrm{HCHO}$ extremes and other data sets}

A cluster of connected spatio-temporal voxels defines an extreme event. These clusters ranked by size and compared with known climate extremes (if any) that occurred at that place and time. This identification was based on literature for the Amazon droughts (Brando et al., 2014; Marengo et al., 2011) and the Russian heatwave 
OMI HCHO columns
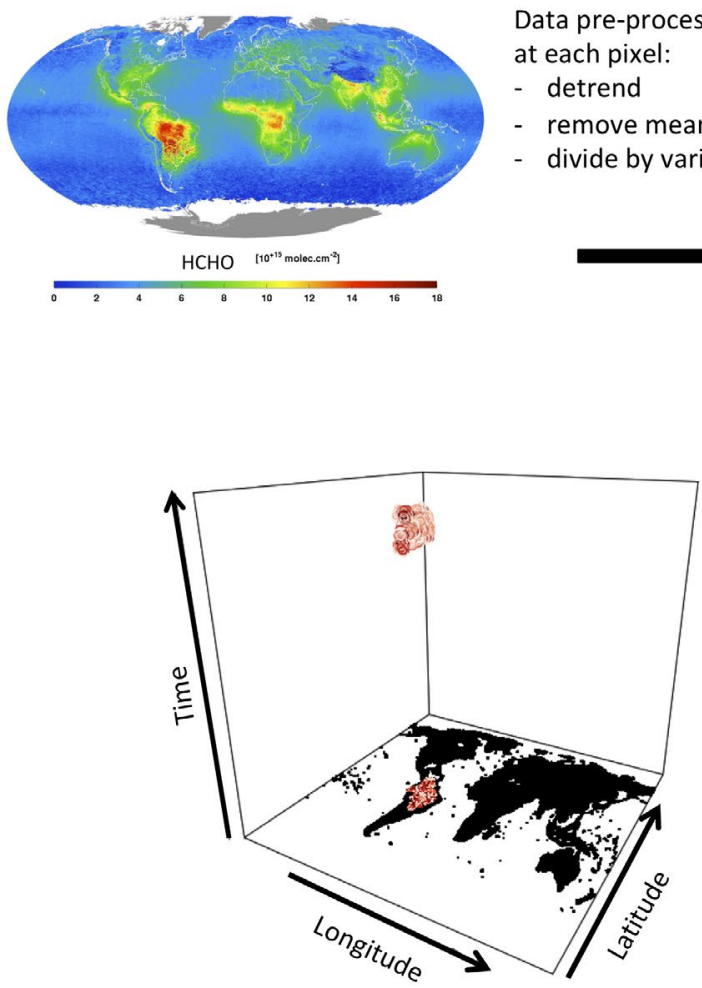

$90 \%$ of the data

Data pre-processing

at each pixel:

- detrend

- remove mean seasonal cycle

divide by variance
Flood-fill algorithm to find large extreme events

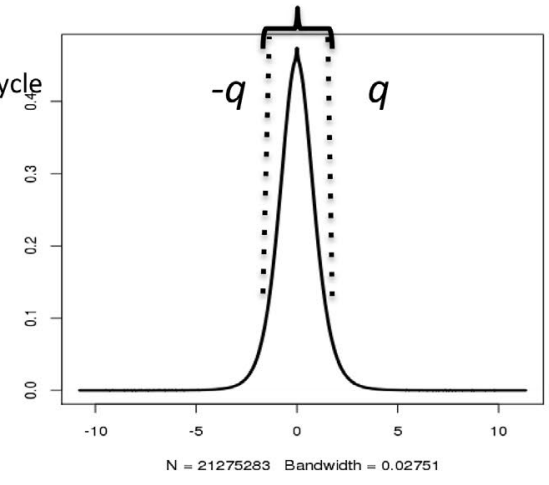

Create a data cube of voxel above (under) the extreme threshold

FIGURE 2 Schematic representing the detection of extremes in OMI-HCHO columns, shown here for the first extreme corresponding to the 2015 El Niño event over South America. HCHO, formaldehyde; OMI, Ozone Monitoring Instrument

(Trenberth \& Fasullo, 2012) and on Multivariate El Niño-Southern Oscillation (ENSO) Index (MEI; MEI >1.5) for the 2015 El Niño event (Wolter \& Timlin, 2011). MEI is available at https://www.esrl.noaa. gov/psd/enso/mei/table.html. We also use information from NOAA State of the Climate reports (https://www.ncdc.noaa.gov/sotc/ global) to identify other significant climate events discussed in this study. To evaluate the vegetation cover potentially impacted by individual climate extremes, we used the SREX regions as defined in the Special Report on Managing the Risks of Extreme Events and Disasters to Advance Climate Change Adaptation (Seneviratne et al., 2012) and the ESA CCI Land Cover time-series v2.0.7 (Hartley et al., 2017; https://www.esa-landcover-cci.org/?q=node/199).

\subsection{Attribution of $\mathrm{OMI} \mathrm{HCHO}$ extremes}

To estimate the role played by BVOC and PVOC in the detected OMI $\mathrm{HCHO}$ positive extremes, we used factors $\alpha_{x}$ (equal to the $\mathrm{HCHO}$ formation yield in the atmospheric oxidation of VOC precursor $x$, multiplied by the atmospheric residence time of $\mathrm{HCHO}$ formed from that precursor) to convert BVOC and PVOC carbon emissions to $\mathrm{HCHO}$ columns in molecules per $\mathrm{cm}^{2}$ (i.e. $\mathrm{HCHO}$ concentration integrated over the atmospheric column) as seen by the OMI satellite. To obtain these factors we performed sensitivity simulations with the IMAGES model to determine the impact of a given emission enhancement ( $+10 \%$ relative to the standard simulation) on the calculated $\mathrm{HCHO}$ columns. This was done separately for isoprene, monoterpenes, methanol and PVOC. The factor $\alpha_{x}$ for a given extreme event is the ratio of the average $\mathrm{HCHO}$ enhancement over the spatio-temporal extent of the event, divided by the average VOC carbon emission enhancement over the same area. Attribution of the contribution of $\mathrm{PVOC}$ and $\mathrm{BVOC}$ to the $\mathrm{HCHO}$ signal was based on absolute anomalies for the spatio-temporal domain of each positive extreme found in the $\mathrm{OMI} \mathrm{HCHO}$ data set.

We performed an additional experiment (noF_HCHO) where extreme detection excluded all pixels for which emissions from biomass burning exceeded the GFED4 monthly climatological mean for 2005-2016. This experiment allowed us to check whether extremes detected using the full $\mathrm{OMI} \mathrm{HCHO}$ data set can be also detected when the contribution of PVOC to the $\mathrm{HCHO}$ signal is (to first order) removed.

\section{3 | RESULTS}

\section{1 $\mathrm{OMI} \mathrm{HCHO}$ extremes and their causes}

The analysis described above, applied to the $\mathrm{HCHO}$ columns, resulted in the identification of $13 \times 10^{7}$ positive extreme anomalies (Figure S1a). The distribution shown does not highlight any particular region of the globe. The decreasing frequency of positive extreme anomalies with latitude reflects the lack of vegetation activity (hence 
BVOC emissions) during winter. After connecting spatially and temporally contiguous voxels experiencing extreme positive anomalies, we obtained 27,545 extremes events of sizes ranging from to 1 to 14,756 voxels. The size distribution of extreme events showed an inverse exponential relationship to their ranking (Figure S1b).

The largest six positive extreme events detected in $\mathrm{HCHO}$ coincide with well-known climatic events, among which five occurred in the tropics (Figure 3). These are the 2015-2016 El Niño over Amazonia (rank 1) and equatorial West Africa (rank 5), and the three severe Amazonian droughts of 2010 (rank 2), 2005 (rank 3) and 2007 (rank 6), detected here in order of drought intensity (Marengo et al., 2011). The only extra-tropical event among the top six was the 2010 Russian heatwave (rank 4). In what follows, we focus on these top six events.

To gain insight into the conditions associated with positive extremes in the $\mathrm{HCHO}$ columns, we integrated the standardized anomalies of key vegetation and climatic variables over the spatiotemporal domain of each of these events (Figure 4; Tables 1 and 2). All six $\mathrm{HCHO}$ positive extremes are associated with positive anomalies in air temperature, LST and solar radiation along with negative anomalies of precipitation, confirming that atmospheric $\mathrm{HCHO}$ production is anomalously large in condition associated to droughts and heatwaves. MODIS LAI, GOME2 SIF and GPP from TRENDY and FLUXCOM all also showed negative anomalies.

Biomass burning emissions data from GFED4s showed numerous outliers of high variance implying increased fire frequency and intensity; but BVOC emissions (isoprene, monoterpenes and methanol) as simulated by MEGAN also showed positive anomalies during these six events (Figure 4). The positive anomalies in both fire and BVOC emissions support the hypothesis that increases in both PVOC and $\mathrm{BVOC}$ contribute to the large positive extremes observed in the $\mathrm{HCHO}$ data. To estimate the respective contributions of BVOC and PVOC emissions, we used the IMAGES model simulations of $\mathrm{HCHO}$ columns. This model captured the top six $\mathrm{HCHO}$ extremes as seen in the OMI record among its top seven positive extremes (extended data Figure S2; Table 3). This agreement between simulated and observed $\mathrm{HCHO}$ extremes implies that they are not observational artefacts, for example, due to the cloud filter, or the interference of heavy aerosol loadings during fires. During the 2005, 2007 and 2010 Amazonian droughts, the $\mathrm{HCHO}$ signal of absolute $\mathrm{HCHO}$ anomalies
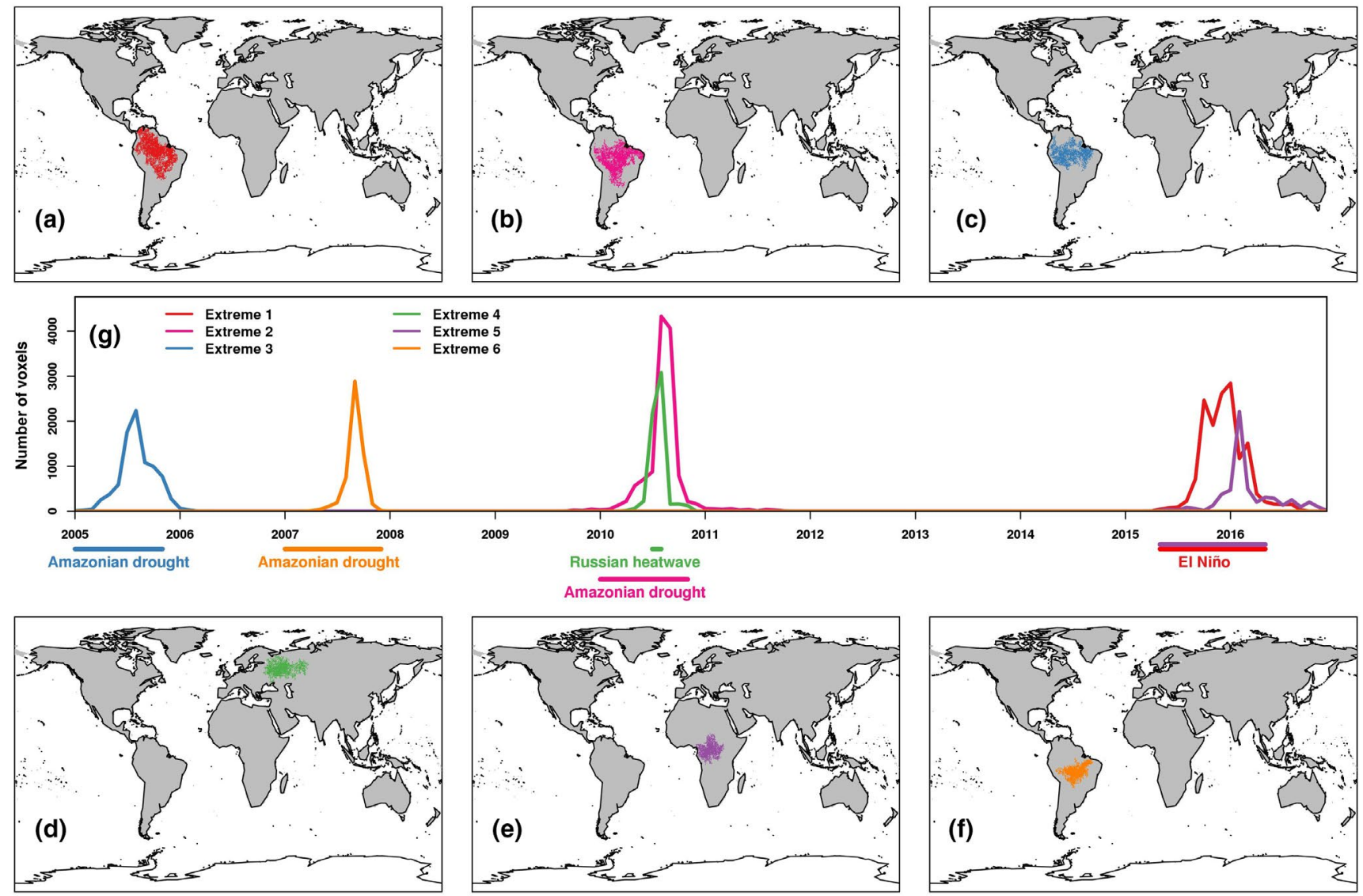

FIGURE 3 Location (panels a-f) and timing (panel g) of the first 6 positive extreme events in the observed OMI HCHO column. Panels a-f show all pixels involved in the identified extreme event for at least 1 month, while panel g shows, for each of these six extremes, the time evolution of the number of voxels involved. Lines underneath the $x$-axis of panel $g$ show the timing of major climatic events as discussed in this study i.e. 2005 (blue), 2007 (orange) and 2010 (pink) Amazonian droughts, 2010 Russian heatwave (green), and 2015 El Niño event (red-magenta). The timing of those events, is based on literature for the Amazon droughts (Brando et al., 2014; Marengo et al., 2011) and the Russian heatwave (Trenberth \& Fasullo, 2012) and on Multivariate ENSO Index (MEI; MEI >1.5) for the 2015 El Niño event (Wolter \& Timlin, 2011). HCHO, formaldehyde; OMI, Ozone Monitoring Instrument 


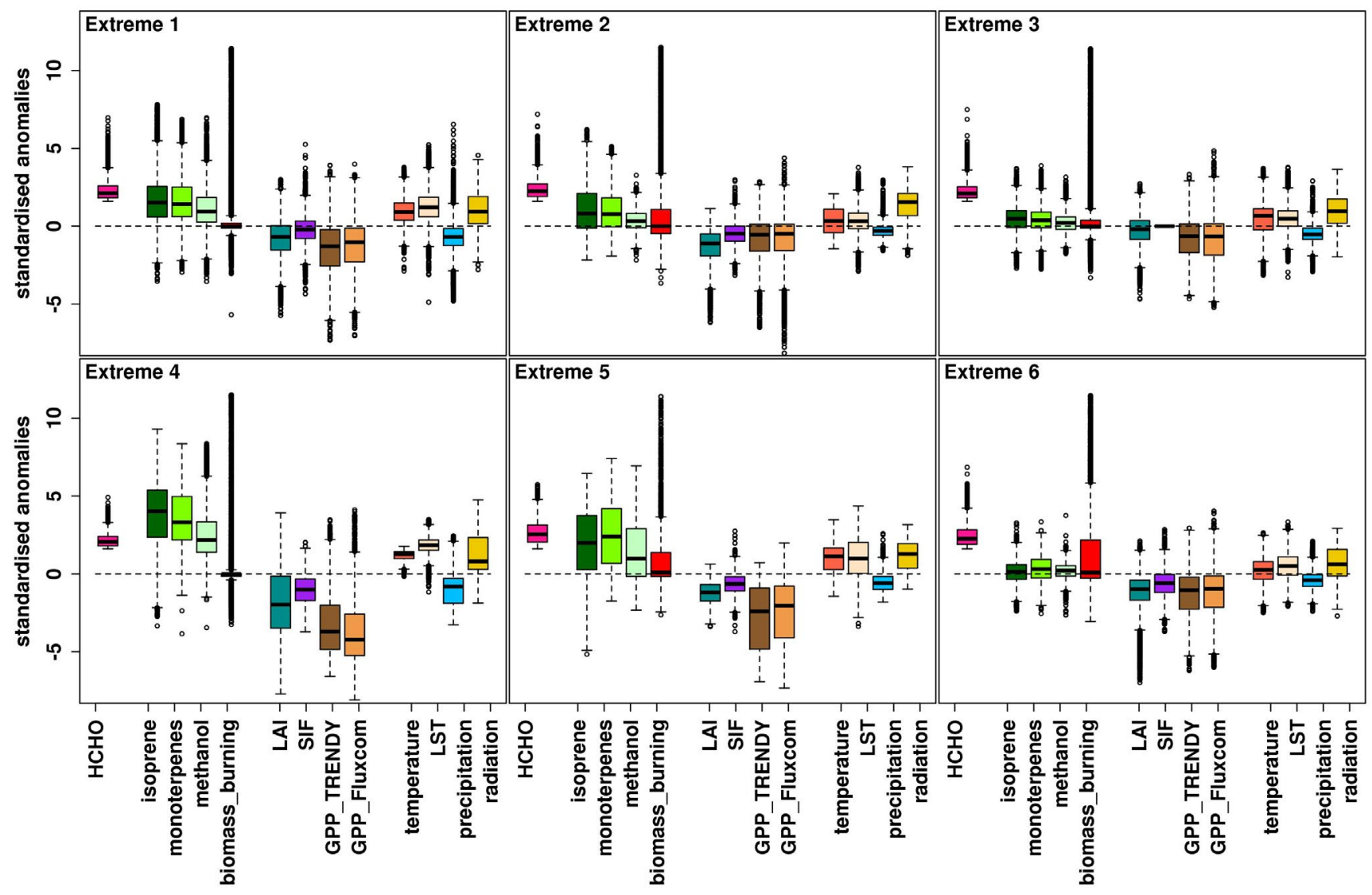

FIGURE 4 Distribution of standardised anomalies of $\mathrm{HCHO}$ sources, vegetation indices and climate drivers for each extreme event observed in $\mathrm{OMI} \mathrm{HCHO}$. Panels a-f show for each of the first six positive extremes events in the observed OMI HCHO column (pink), the corresponding anomalies for (from left to right): isoprene, monoterpenes and methanol as simulated by MEGAN (respectively in dark green, green, light green), GFED4s biomass burning carbon emissions (red), MODIS LAI (dark blue), GOME2 SIF (purple), TRENDY GPP (dark brown), FLUXCOM GPP (light brown), CRU temperature (orange), MODIS LST (cream), CRU precipitation (blue) and NCEP-NCAR short-wave radiation (yellow). Bar plots show the distribution of the standardised anomalies at the spatio-temporal domain of each $\mathrm{HCHO}$ positive extreme. The boxes indicate the interquartile range and median values. Whiskers extend to the largest or smallest observation that fall within 1.5 times the box size; any observations outside these values are shown as individual points. GPP, gross primary production; $\mathrm{HCHO}$, formaldehyde; LAI, leaf area index; LST, land surface temperature; OMI, Ozone Monitoring Instrument; SIF, solar-induced passive fluorescence

TAB LE 1 Mean absolute anomaly $\left(10^{15}\right.$ molecules $\left.\mathrm{cm}^{-2}\right)$ calculated for observed (OMI) and simulated (IMAGES) HCHO over the spatiotemporal domain of the first six positive extremes detected in $\mathrm{OMI} \mathrm{HCHO}$ columns. Attribution of $\mathrm{HCHO}$ mean anomaly modelled by IMAGES to sources of isoprene, monoterpenes, methanol and PVOC (in \%, rounded to the nearest integer)

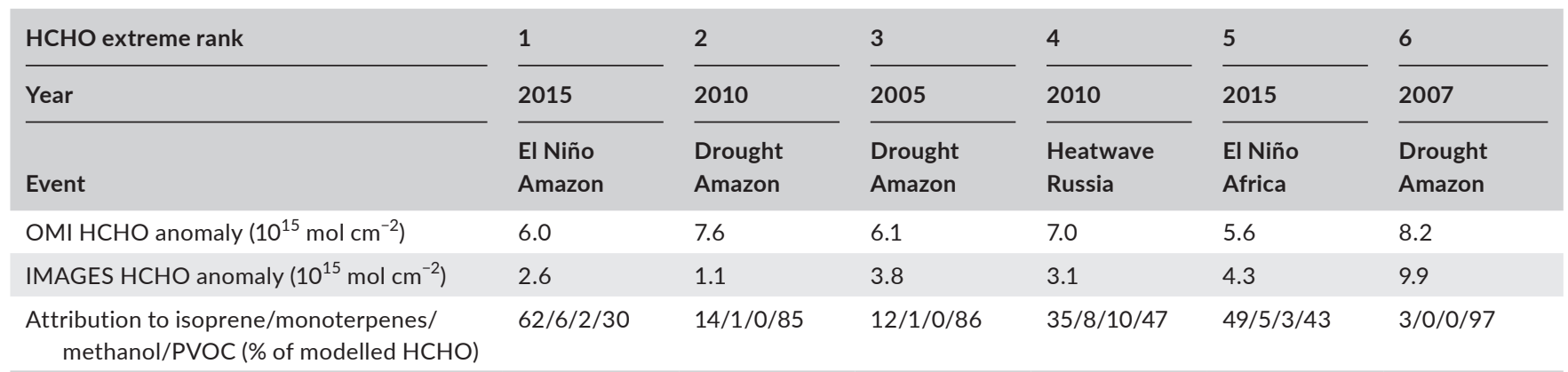

Abbreviations: $\mathrm{HCHO}$, formaldehyde; OMI, Ozone Monitoring Instrument; PVOC, pyrogenic volatile organic compound.

was dominated by PVOCs (contributing over $85 \%$ of the modelled $\mathrm{HCHO}$ absolute anomaly during each event: Table 1). In contrast, for the two extremes associated with the El Niño of 2015-2016, BVOCs anomalies were the dominant contribution to the modelled
$\mathrm{HCHO}$ signal, accounting for about $70 \%$ over Amazonia and $57 \%$ in West Africa. During the 2010 Russian heatwave, PVOC and BVOC equally influenced the modelled $\mathrm{HCHO}$. For all identified extremes, isoprene dominated the biogenic signal, with a contribution to the 
TAB LE 2 Mean absolute anomaly calculated for MODIS LAI, TRENDY GPP, FLUXCOM GPP, MODIS LST, CRU air temperature and precipitation and NCEP-NCAR net shortwave radiation over the spatio-temporal domain of the first six positive extremes detected in OMI $\mathrm{HCHO}$ columns. Percentage of voxels for which the BVOC signal dominates over the PVOC signal using IMAGES modelling (i.e. $>50 \%$ of $\mathrm{HCHO}$ calculated at the voxels originates from BVOC)

\begin{tabular}{|c|c|c|c|c|c|c|}
\hline $\mathrm{HCHO}$ extreme rank & 1 & 2 & 3 & 4 & 5 & 6 \\
\hline $\mathrm{LAl}$ anomaly $\left(\mathrm{m}^{2} \mathrm{~m}^{-2}\right)$ & -0.4 & -0.6 & -0.1 & -0.5 & -0.6 & -0.5 \\
\hline LST anomaly $\left({ }^{\circ} \mathrm{C}\right)$ & 1.1 & 0.3 & 0.5 & 6.1 & 0.8 & 0.5 \\
\hline Air temperature anomaly $\left({ }^{\circ} \mathrm{C}\right)$ & 0.5 & 0.2 & 0.2 & 2.8 & 0.5 & 0.1 \\
\hline Precipitation anomaly (mm) & -41 & -14 & -30 & -21 & -17 & -13 \\
\hline Net shortwave radiation anomaly $\left(\mathrm{Wm}^{-2}\right)$ & 8.7 & 11.3 & 7.2 & 9.9 & 10.5 & 6.4 \\
\hline
\end{tabular}

Abbreviations: BVOC, biogenic volatile organic compound; $\mathrm{HCHO}$, formaldehyde; OMI, Ozone Monitoring Instrument; PVOC, pyrogenic volatile organic compound.

total BVOC anomalies ranging between $66 \%$ and $100 \%$, followed by monoterpenes (0\%-15\%) and methanol (0\%-18\%; Table 1).

Pyrogenic volatile organic compound emissions originate from one-off events of extremely high carbon emission (10-100 times higher than through BVOCs). For the three Amazonian droughts, these large $\mathrm{PVOC}$ emissions dominate the $\mathrm{HCHO}$ signal when integrated over the entire spatio-temporal domain, masking the role of less intense, but more spatially extensive BVOC emissions (extended data Figure S3; Table 2). Even if we cannot entirely exclude the influence of horizontal atmospheric transport of PVOC-derived $\mathrm{HCHO}$, these results suggest a significant role for BVOC emissions during extreme conditions for all the detected events. Moreover, masking pixels experiencing unusual biomass burning (Table 3; extended data Figure S4) had little influence on the correspondence between extremes detected in $\mathrm{HCHO}$ and climatic extreme events-apart from the 2015 El Niño over West Africa, which fell from rank 5 to 14.

\subsection{Extremes detected in other data sets}

The correspondence between extreme events detected in $\mathrm{HCHO}$ and in alternative data sets (in term of size ranking) is shown in Table 3; extended data Figure S4.

Among its top six negative extremes, MODIS LAl detected the 2007 Amazonian drought and the 2010 Russian heatwave. Other extremes corresponded to the summer of 2009 in central Europe (not reported as a significant event by NOAA global climate report), the 2005 African drought, the 2012 USA summer drought and the 2015 warm summer in Canada. The 2005 and 2010 Amazonian droughts, and the 2015-2016 El Niño event, fell above the first thirteen negative LAI extremes (Table 3; extended data Figures S4 and S5).

SIF data showed negative extremes corresponding only to the 2007 drought in Amazonia and the 2015 El Niño event over West
Africa. Among its top six negative extremes, SIF detected the 2012 and 2011 US summer droughts, and an extreme in 2007 over South Africa (not reported as a significant event by NOAA global climate report). The 2010 Russian heatwave was detected at rank 8, but the 2015-2016 El Niño over South America and the 2010 Amazonian drought were detected at ranks 33 and 185, respectively (Table 3; extended data Figures S4 and S6).

Negative extremes in TRENDY GPP captured only the 20152016 El Niño over South America among the top six detected extremes. The 2010 Russian heatwave was detected at rank 8 , and the 2015-2016 El Niño over Africa at rank 9. Negative extremes corresponding to the 2005, 2007 and 2010 Amazonian droughts were ranked 31 or above. Other detected extremes corresponded to the 2005 African drought, the 2012 USA summer drought, spring 2006 in Russia and spring 2008 in southwest Asia (not reported as a significant event by NOAA global climate report; Table 3; extended data Figures S4 and S7).

Similar to TRENDY GPP, FLUXCOM GPP captured only the 2015-2016 El Niño over South America among the top six detected extremes. The 2010 Russian heatwave was detected at rank 7, and the 2015-2016 El Niño over Africa at rank 13. Negative extremes corresponding to the 2005, 2007 and 2010 Amazonian droughts were ranked 20 or above. In contrast to TRENDY GPP, the 5 remaining top extreme events detected in FLUXCOM GPP occur mainly in Eurasia, primarily in Russia, for 5 consecutive years (2011-2015). Four out of the 5 years i.e. 2012-2015 are considered as significant warm years according to NOAA global climate report (Table 3; extended data Figures S4 and S8).

The same detection method applied to the main climatic variables returned a more ambiguous picture (extended data Figures S9-S11). Surface air temperature detected only the 2015-2016 El Niño over equatorial West Africa among its top six positive extremes. Extremes of surface air temperature were mainly warm winters 
TABLE 3 Known climatic extreme events and their correspondence in extreme ranking and size of positive extremes detected in the $\mathrm{OMI} \mathrm{HCHO}$, noF-HCHO (i.e. OMI-HCHO with biomass burning masked), IMAGES, CRU air temperature, MODIS LST, NCEP-NCAR net shortwave radiation and negative extremes detected for MODIS LAI, GOME-SIF, TRENDY GPP, FLUXCOM GPP and CRU precipitation data sets

\begin{tabular}{|c|c|c|c|c|c|c|}
\hline & $\begin{array}{l}2015 \\
\text { El Niño } \\
\text { Amazon }\end{array}$ & $\begin{array}{l}2010 \\
\text { Drought } \\
\text { Amazon }\end{array}$ & $\begin{array}{l}2005 \\
\text { Drought } \\
\text { Amazon }\end{array}$ & $\begin{array}{l}2010 \\
\text { Heatwave } \\
\text { Russia }\end{array}$ & $\begin{array}{l}2015 \\
\text { El Niño } \\
\text { West Africa }\end{array}$ & $\begin{array}{l}2007 \\
\text { Drought } \\
\text { Amazon }\end{array}$ \\
\hline \multicolumn{7}{|l|}{$\mathrm{HCHO}$} \\
\hline Ranking & 1 & 2 & 3 & 4 & 5 & 6 \\
\hline Size & 14,756 & 12,584 & 8520 & 5997 & 5533 & 5449 \\
\hline \multicolumn{7}{|l|}{ noF-HCHO } \\
\hline Ranking & 2 & 1 & 4 & 3 & 14 & 6 \\
\hline Size & 7572 & 11,207 & 5600 & 6882 & 1535 & 2726 \\
\hline \multicolumn{7}{|l|}{ IMAGES } \\
\hline Ranking & 1 & 5 & 6 & 4 & 2 & 7 \\
\hline Size & 32,736 & 22,562 & 21,126 & 27,460 & 30,591 & 18,334 \\
\hline \multicolumn{7}{|l|}{ LAI } \\
\hline Ranking & 16 & 13 & 14 & 4 & 21 & 1 \\
\hline Size & 8055 & 8737 & 8673 & 19,649 & 6453 & 21,952 \\
\hline \multicolumn{7}{|l|}{ SIF } \\
\hline Ranking & 33 & 185 & NA & 8 & 2 & 4 \\
\hline Size & 1298 & 270 & NA & 3486 & 6640 & 6177 \\
\hline \multicolumn{7}{|l|}{ TRENDY } \\
\hline Ranking & 2 & 47 & 41 & 8 & 9 & 33 \\
\hline Size & 28,489 & 5926 & 6413 & 19,500 & 19,492 & 8953 \\
\hline \multicolumn{7}{|l|}{ FLUXCOM } \\
\hline Ranking & 3 & 41 & 32 & 7 & 13 & 20 \\
\hline Size & 30,550 & 7142 & 8396 & 27,994 & 17,772 & 13,432 \\
\hline \multicolumn{7}{|l|}{$T_{\text {air }}$} \\
\hline Ranking & 7 & 8 & 30 & 22 & 6 & 66 \\
\hline Size & 28,520 & 27,651 & 5973 & 9431 & 29,266 & 3051 \\
\hline \multicolumn{7}{|l|}{ LST } \\
\hline Ranking & 4 & 18 & 46 & 21 & 27 & 28 \\
\hline Size & 27,938 & 9756 & 3842 & 8982 & 6702 & 6407 \\
\hline \multicolumn{7}{|c|}{ Precipitation } \\
\hline Ranking & 24 & 59 & 32 & 4 & 18 & 3 \\
\hline Size & 4338 & 2508 & 3567 & 11,271 & 5298 & 11,383 \\
\hline \multicolumn{7}{|l|}{ Radiation } \\
\hline Ranking & 10 & 28 & 25 & 15 & 13 & 73 \\
\hline Size & 15,911 & 7530 & 8225 & 12,360 & 12,959 & 2886 \\
\hline
\end{tabular}

Abbreviations: $\mathrm{HCHO}$, formaldehyde; OMI, Ozone Monitoring Instrument.
(2006, 2007, 2008, 2016) in the Northern Hemisphere and the 2005 African drought. The 2015-2016 El Niño and the 2010 drought over Amazonia were detected at rank 7 and 8, respectively. The 2010 Russian heatwave and the 2005 and 2007 Amazonian droughts were detected at ranks of 22 or above (Table 3; extended data Figures S4 and S9).

Precipitation negative extremes detected the 2010 Russian heatwave and the 2007 Amazonian drought. The largest negative extremes of precipitation occurred mainly during summers over East Asia. The other climatic extremes detected in the $\mathrm{HCHO}$ columns were detected in precipitation data at ranks of 18 or above (Table 3; extended data Figures S4 and S10).
Positive extremes of short-wave radiation did not include any of those detected by $\mathrm{HCHO}$ among its top 10 (Table 3; extended data Figures S4 and S11). The top six positive extremes of shortwave radiation include the warm year of 2014 in Europe, the 2012 US drought, the 2016 warm year over Asia, the 2010 warm spring in Canada, and the 2014 warm spring in Russia. The event detected at rank 4 does not correspond to any known climatic event.

Finally, positive extremes in MODIS LST detected the 20152016 El Niño over South America, but other climatic extremes detected in the $\mathrm{HCHO}$ columns were ranked at 18 or higher. As for air temperature, the first six positive LST extremes mainly relate to warm winters $(2007,2008,2009)$ in the Northern Hemisphere. The 
2005 African drought and spring 2012 over the USA also triggered positive extremes in MODIS LST (Table 3; extended data Figures S4 and S12).

\section{4 | DISCUSSION}

We have successfully used a robust detection method to identify positive extremes in remotely sensed $\mathrm{HCHO}$ columns. $\mathrm{HCHO}$ has long been used to infer isoprene emissions (Marais et al., 2012; Palmer et al., 2003) with a focus on atmospheric chemistry. Here, we show that $\mathrm{HCHO}$ data have the potential to provide key information on the response of vegetation state to extreme climate events, particularly in forested regions. Positive extremes identified in $\mathrm{HCHO}$ data coincide with important climatic extreme events, each of which potentially affecting between 10 to $20 \%$ of forest cover in the World (Table 4). Confronting results from remotely sensed $\mathrm{HCHO}$ and IMAGES simulations show good consistency, suggesting that our results are robust despite potential signal disturbance due to cloud and aerosol contamination in remotely sensed $\mathrm{HCHO}$. The strong response of BVOC emissions to heat and drought stress appears to be the main driver for these extremes. This is an important property since, to sustain high BVOC emissions, the photosynthetic apparatus (not only the leaf area) must remain functional. Although both the light reactions (absorption of solar radiation by chlorophyll) and the dark reactions $\left(\mathrm{CO}_{2}\right.$ assimilation by Rubisco) of photosynthesis can function under normal conditions, $\mathrm{CO}_{2}$ assimilation is suppressed due to stomatal closure under moderate to mild drought, whereas the photosynthetic apparatus is not damaged (Cornic \& Briantais, 1991). Under more severe drought, this reduction is strengthened by decreased ATP synthesis in water-deficient leaves (Lawlor \& Tezara, 2009), thereby further reducing photosynthetic metabolism. The resulting oversupply of reducing power ensures that BVOC emissions can continue at a high rate even when carbon assimilation is reduced (Morfopoulosl et al., 2013; Niinemets et al., 2010). Thus, the observation of positive extremes in $\mathrm{HCHO}$ during extreme heat and/or drought events indicates not only a decoupling between vegetation structure and carbon assimilation but also that the light-harvesting capacity of plants remains intact, at least in isoprenoids-emitting plants.

We have shown that $\mathrm{HCHO}$ has the ability to track large-scale responses to important climate extremes in forest vegetation, identified as potentially significant for the carbon cycle, that is, the 2015-2016 El Niño over the South America and Africa, the 2010 and 2005 Amazonian droughts and the 2010 Russian heatwave (Barriopedro et al., 2011; Lewis et al., 2011; Liu et al., 2017; Rasmijn et al., 2018; Saleska et al., 2007). All these extremes left a substantial imprint in the atmospheric $\mathrm{HCHO}$ columns. Indeed, these climate events are detected in the $\mathrm{HCHO}$ positive extremes events, more consistently than in LAI and SIF, or in any single climatic variable. This can be explained in part by plants' reliance on NPQ via the xanthophyll cycle as a means to dissipate excess energy. The biosynthesis of xanthophyll pigments takes place through the same pathway as isoprenoid BVOCs (including isoprene and monoterpenes). In the absence of fire, changes in $\mathrm{HCHO}$ column concentrations can be directly linked to change in BVOC emissions, which are concomitant with a rise in the xanthophyll content of leaves (Peñuelas et al., 2013). Moreover, using a meta-analytical approach, Esteban et al. (2015) showed that, under drought conditions the xanthophyll: chlorophyll ratio increases by about $50 \%$ compared to non-stressed conditions. Under the same conditions, the concentration of chlorophyll $a+b$ decreases by only by a few per cent. Therefore the plant can remain 'green' while being under high abiotic stress. Additionally, it has been demonstrated that Amazonian tree mortality is mainly due to hydraulic failure rather than carbon starvation (Rowland et al., 2015), suggesting an important NPQ defence mechanism. Our results support the hypothesis that BVOC emissions, in particular isoprene, play a central role in tropical forest resilience to drought and high temperature (Smith et al., 2020; Taylor et al., 2019). If only

TAB LE 4 Proportion (in \%) of world vegetation potentially affected by known climate significant events corresponding to the first six extremes detected in the OMI HCHO, MODIS LAI and GOME-SIF. Percentages of impacted vegetation are based on SREX regions potentially affected by the climate events combined with information on land cover from ESA CCI Land Cover time-series v2.0.7 (extended data Figure S13)

\begin{tabular}{|c|c|c|c|c|c|c|}
\hline SREX regions & Climate significant events & $\begin{array}{l}\text { Mean event } \\
\text { duration (month) }\end{array}$ & $\begin{array}{l}\text { Vegetation \% } \\
\text { of the world }\end{array}$ & $\begin{array}{l}\text { Forest \% of } \\
\text { the world }\end{array}$ & $\begin{array}{l}\text { Shrub \% of } \\
\text { the world }\end{array}$ & $\begin{array}{l}\text { Grassland \% } \\
\text { of the world }\end{array}$ \\
\hline 7,8 & $\begin{array}{l}\text { El Niño (2015-2016) over South } \\
\text { America } \\
\text { Amazonian droughts }(2010, \\
2005,2007)^{\mathrm{a}}\end{array}$ & 11 & 11 & 18 & 10 & 6 \\
\hline 15,16 & $\begin{array}{c}\text { El Niño (2015-2016) over } \\
\text { Equatorial Africa }^{\text {a }}\end{array}$ & 11 & 12 & 10 & 16 & 14 \\
\hline 18 & Russian Heatwave $(2010)^{a}$ & 3 & 13 & 20 & 12 & 10 \\
\hline 5,6 & USA drought $(2011,2012)$ & 4 & 6 & 5 & 4 & 7 \\
\hline 17 & Southern Africa drought (2005) & 12 & 5 & 3 & 9 & 5 \\
\hline 1,2 & Canadian warm summer (2015) & 3 & 0.6 & 7 & 5 & 0.5 \\
\hline
\end{tabular}

Abbreviations: $\mathrm{HCHO}$, formaldehyde; OMI, Ozone Monitoring Instrument.

${ }^{\mathrm{a}} \mathrm{Significant}$ events detected in the formaldehyde columns. 
about $20 \%-38 \%$ of tropical plants are isoprene emitters, the dominant species from the top five genera, representing about $50 \%$ of all individuals in the Amazonian basin, have a large abundance of isoprenoids emitters ( $80 \%$; Jardine et al., 2020). Isoprenoids emission is a significant plant trait in tree response to increasing droughts improving forest resilience. Yet it is still unclear if tropical forest composition will shift towards higher isoprenoids emitters or other traits such as leaf deciduousness (Taylor et al., 2018).Our results indicate that $\mathrm{HCHO}$ is more sensitive than any climatic variable or satellite-derived vegetation product explored in this study to climate extremes such as droughts and heatwaves where water scarcity is associated with high temperature, particularly over forested areas. Variations in the $\mathrm{HCHO}$ columns are mainly controlled by BVOC emissions, which are expected to take place only when vegetation is active (Palmer et al., 2003). This is in contrast to climate data alone, which performed poorly in our analyses as predictors of vegetation stress, and identified many extremes during northern winter when vegetation is inactive. Satellite-based products based on visible and near-infrared reflectance, such as LAI, are dependent on chlorophyll concentration, which does not vary much under drought stress (Esteban et al., 2015) unless the plant defoliates. These products also tend to saturate in the Tropics and are sensitive to cloud and aerosol contamination (Hashimoto et al., 2021; Hilker et al., 2014). Thus it is not surprising that chlorophyll-based satellite products catches climate events where plants defoliate under drought conditions (i.e. grassland and croplands ecosystems), such as the 2012 US drought or the 2005 African drought. The same applies to SIF, which is also chlorophyll dependent, although less sensitive to cloud contamination. Yet, it is surprising that despite a clear connection between MODIS LAI and GOME SIF (i.e. chlorophyll concentration), extremes in the two products do not match and reveal several extremes that do not correspond to any climate significant event. This mismatch might be due to the differences in spatial resolution for detection between both products.

Tropical forests play a crucial role in the global carbon cycle (Le Quéré et al., 2009; Pan et al., 2011), yet observations of GPP in tropical forests are still limited, making it difficult to constrain the effect of climate change and extremes on GPP at a large scale. The connection between increase in $\mathrm{HCHO}$ and GPP loss under drought is however not straightforward and would require further investigation using a modelling approach linking GPP and isoprenoids emission. Yet, carbon cost that can amount for about $2 \%$ of the leaf net carbon assimilation under non-stressed conditions, this loss can be significantly larger under hightemperature conditions (Lerdau \& Throop, 1999; Sharkey \& Loreto, 1993). For instance, the study by Parveen et al. (2019) found out that tropical ficus septica presented twice more isoprene emission under drought while net carbon assimilation was lowered by $90.6 \%$, increasing the carbon lost in isoprene emission from $\sim 1.7 \%$ under normal conditions to $\sim 40 \%$ under drought conditions. Thus we argue that carbon loss estimates solely based on remotely sensed 'greenness' are likely to underestimate carbon loss during drought events in the Tropics.

The repeated droughts experienced over recent decades have had a significant impact on ecosystem dynamics and carbon cycling in tropical forests (Brienen et al., 2015; Doughty et al., 2015; Feldpausch et al., 2016). The ability to produce BVOC is a key defence mechanism against the effects of heat and drought, accounting for the unique suitability of $\mathrm{HCHO}$ as a sensor of vegetation stress and NPQ response. Very recent direct satellite-based retrievals of atmospheric isoprene concur with our finding that the interannual variation of BVOC emission in the tropics is tied to El Niño (Wells et al., 2020). Meanwhile, $\mathrm{HCHO}-$ as a joint indicator of biogenic and pyrogenic emissions-has the advantage of being routinely measured from space and a valuable indicator of the effects of climate extremes on the coupled vegetationatmosphere system at regional to global scales.

\section{ACKNOWLEDGEMENTS}

This research has been partly supported by the projects PRODEX TROVA of the European Space Agency and ALBERI (SR/00/373) funded by the Belgian Science Policy Office (2016-2019), as well as OCTAVE (BR/175/A2/OCTAVE) of the Belgian Research Action through Interdisciplinary Networks (BRAIN-be) research programme (2017-2021). I.D.S. received financial support from the FP7 QA4ECV project (grant agreement no: 607405). C.M., P.F. and P.R. received financial support from BELSPO through the project 'Global impacts of hydrological and climatic extremes on vegetation' (SAT-EX, $\mathrm{SR} / 00 / 306)$, which is part of the Belgian research programme for Earth Observation Stereo III. I.C.P. and C.M. acknowledge support from the European Research Council under the European Union's Horizon 2020 research and innovation programme (grant agreement no: 787203 REALM). This research is a contribution to the Imperial College initiative on Grand Challenges in Ecosystems and the Environment. We also want to thank Mike O'Sullivan for providing remapped ESA CCI Land Cover time-series v2.0.7.

\section{CONFLICT OF INTEREST}

The authors declare no competing interests.

\section{AUTHOR CONTRIBUTIONS}

C.M. designed the study and conducted the analyses with support by J-F.M., T.S., I.D.S., P.R. and P.F. J-F.M. and T.S. made the simulations with IMAGES. MB prepared the LST data set. C.M. drafted the paper with contributions. All authors discussed the results and commented on the paper.

\section{DATA AVAILABILITY STATEMENT}

The data that support the findings of this study are openly available in: $\mathrm{HCHO}$ data: http://www.qa4ecv.eu, Air temperature and precipitation: http://www.cru.uea.ac.uk/, Net short-wave radiation: https://www.esrl.noaa.gov/psd/data/gridded/data.ncep.reanalysis. derived.surfaceflux.html, MODIS LAI: http://cliveg.bu.edu/modis misr/lai3g-fpar3g.html, SIF: https://avdc.gsfc.nasa.gov/pub/data/ satellite/MetOp/GOME_F/, Global Fire Emissions Database including small fires (GFED4s): www.globalfiredata.org, Land Surface Temperature (LST): https://modis-land.gsfc.nasa.gov/, BVOC emissions were simulated by the Model of Emissions of Gases and Aerosols from Nature version 2.1 (MEGAN2.1): https://bai.ess.uci. 
edu/megan/data-and-code/megan21, Gross Primary Production (GPP): http://www-lscedods.cea.fr/invsat/RECCAP/, Multivariate

El Niño-Southern Oscillation (ENSO) Index: https://www.esrl. noaa.gov/psd/enso/mei/table.html, FLUXCOM Gross Primary Production (GPP): http://www.fluxcom.org/CF-Products/ and ESA CCI Land Cover time-series v2.0.7: https://www.esa-landcover-cci. $\operatorname{org} /$ ?q=node/199.

\section{ORCID}

Catherine Morfopoulos (D) https://orcid.org/0000-0002-6121-2483

\section{REFERENCES}

Alonso, L., Wittenberghe, S. V., Amorós-López, J., Vila-Francés, J., Gómez-Chova, L., \& Moreno, J. (2017). Diurnal cycle relationships between passive fluorescence, $\mathrm{PRI}$ and NPQ of vegetation in a controlled stress experiment. Remote Sensing, 9(8), 770. https://doi. org/10.3390/rs9080770

Andreae, M. O. (2019). Emission of trace gases and aerosols from biomass burning-An updated assessment. Atmospheric Chemistry and Physics, 19(13), 8523-8546. https://doi.org/10.5194/ acp-19-8523-2019

Barriopedro, D., Fischer, E. M., Luterbacher, J., Trigo, R. M., \& GarcíaHerrera, R. (2011). The hot summer of 2010: Redrawing the temperature record map of Europe. Science, 332(6026), 220-224. https://doi.org/10.1126/science.1201224

Bauwens, M., Stavrakou, T., Müller, J.-F., De Smedt, I., Van Roozendael, M., van der Werf, G. R., Wiedinmyer, C., Kaiser, J. W., Sindelarova, K., \& Guenther, A. (2016). Nine years of global hydrocarbon emissions based on source inversion of OMI formaldehyde observations. Atmospheric Chemistry and Physics, 16(15), 10133-10158. https://doi.org/10.5194/acp-16-10133-2016

Bowman, D. M. J. S., Balch, J., Artaxo, P., Bond, W. J., Cochrane, M. A., D'Antonio, C. M., DeFries, R., Johnston, F. H., Keeley, J. E., Krawchuk, M. A., Kull, C. A., Mack, M., Moritz, M. A., Pyne, S., Roos, C. I., Scott, A. C., Sodhi, N. S., \& Swetnam, T. W. (2011). The human dimension of fire regimes on Earth. Journal of Biogeography, 38(12), 2223-2236. https://doi.org/10.1111/j.1365-2699.2011.02595.x

Brando, P. M., Balch, J. K., Nepstad, D. C., Morton, D. C., Putz, F. E., Coe, M. T., Silverio, D., Macedo, M. N., Davidson, E. A., Nobrega, C. C., Alencar, A., \& Soares-Filho, B. S. (2014). Abrupt increases in Amazonian tree mortality due to drought-fire interactions. Proceedings of the National Academy of Sciences of the United States of America, 111(17), 6347-6352. https://doi.org/10.1073/ pnas.1305499111

Brasseur, G., Orlando, J. J., \& Tyndall, G. S. (1999). Atmospheric chemistry and global change. Oxford University Press. https://books.google. $\mathrm{fr} /$ books? id=eLAiOeWzDssC

Brienen, R. J. W., Phillips, O. L., Feldpausch, T. R., Gloor, E., Baker, T. R., Lloyd, J., Lopez-Gonzalez, G., Monteagudo-Mendoza, A., Malhi, Y., Lewis, S. L., Vásquez Martinez, R., Alexiades, M., Álvarez Dávila, E., Alvarez-Loayza, P., Andrade, A., Aragão, L. E. O. C., AraujoMurakami, A., Arets, E. J. M. M., Arroyo, L., ... Zagt, R. J. (2015). Long-term decline of the Amazon carbon sink. Nature, 519(7543), 344-348. https://doi.org/10.1038/nature14283

Brilli,F.,Barta,C., Fortunati,A., Lerdau,M.,Loreto,F., \& Centritto,M.(2007). Response of isoprene emission and carbon metabolism to drought in white poplar (Populus alba) saplings. The New Phytologist, 175(2), 244-254. https://doi.org/10.1111/j.1469-8137.2007.02094.x

Chen, A., Mao, J., Ricciuto, D., Xiao, J., Frankenberg, C., Li, X., Thornton, P. E., Gu, L., \& Knapp, A. K. (2021). Moisture availability mediates the relationship between terrestrial gross primary production and solar-induced chlorophyll fluorescence: Insights from global-scale variations. Global Change Biology, 27(6), 1144-1156. https://doi. org/10.1111/gcb.15373

Cornic, G., \& Briantais, J.-M. (1991). Partitioning of photosynthetic electron flow between $\mathrm{CO}_{2}$ and $\mathrm{O}_{2}$ reduction in a $\mathrm{C} 3$ leaf (Phaseolus vulgaris L.) at different $\mathrm{CO}_{2}$ concentrations and during drought stress. Planta, 183(2), 178-184. https://doi.org/10.1007/BF00197786

De Smedt, I., Theys, N., Yu, H., Danckaert, T., Lerot, C., Compernolle, S., Van Roozendael, M., Richter, A., Hilboll, A., Peters, E., Pedergnana, M., Loyola, D., Beirle, S., Wagner, T., Eskes, H., van Geffen, J., Boersma, K. F., \& Veefkind, P. (2018). Algorithm theoretical baseline for formaldehyde retrievals from S5P TROPOMI and from the QA4ECV project. Atmospheric Measurement Techniques, 11, 23952426. https://doi.org/10.5194/amt-11-2395-2018

Doughty, C. E., Metcalfe, D. B., Girardin, C. A. J., Amézquita, F. F., Cabrera, D. G., Huasco, W. H., Silva-Espejo, J. E., Araujo-Murakami, A., da Costa, M. C., Rocha, W., Feldpausch, T. R., Mendoza, A. L. M., da Costa, A. C. L., Meir, P., Phillips, O. L., \& Malhi, Y. (2015). Drought impact on forest carbon dynamics and fluxes in Amazonia. Nature, 519(7541), 78-82. https://doi.org/10.1038/nature14213

Esteban, R., Barrutia, O., Artetxe, U., Fernández-Marín, B., Hernández, A., \& García-Plazaola, J. I. (2015). Internal and external factors affecting photosynthetic pigment composition in plants: A metaanalytical approach. New Phytologist, 206(1), 268-280. https://doi. org/10.1111/nph.13186

Fang, C., Monson, R. K., \& Cowling, E. B. (1996). Isoprene emission, photosynthesis, and growth in sweetgum (Liquidambar styraciflua) seedlings exposed to short- and long-term drying cycles. Tree Physiology, 16, 441-446. https://doi.org/10.1093/treephys/16.4.441

Feldpausch, T. R., Phillips, O. L., Brienen, R. J. W., Gloor, E., Lloyd, J., Lopez-Gonzalez, G., Monteagudo-Mendoza, A., Malhi, Y., Alarcón, A., Álvarez Dávila, E., Alvarez-Loayza, P., Andrade, A., Aragao, L. E. O. C., Arroyo, L., Aymard, C. G. A., Baker, T. R., Baraloto, C., Barroso, J., Bonal, D., ... Vos, V. A. (2016). Amazon forest response to repeated droughts. Global Biogeochemical Cycles, 30(7), 964-982. https://doi.org/10.1002/2015GB005133

Filella, I., Zhang, C., Seco, R., Potosnak, M., Guenther, A., Karl, T., Gamon, J., Pallardy, S., Gu, L., Kim, S., Balzarolo, M., Fernandez-Martinez, M., \& Penuelas, J. (2018). A MODIS photochemical reflectance index (PRI) as an estimator of isoprene emissions in a temperate deciduous forest. Remote Sensing, 10(4), 557. https://doi.org/10.3390/ rs10040557

Frankenberg, C., \& Berry, J. (2017). Solar induced chlorophyll fluorescence: Origins, relation to photosynthesis and retrieval. In Comprehensive remote sensing (Vol. 1-9). Elsevier. https://doi. org/10.1016/B978-0-12-409548-9.10632-3

Guenther, A., Hewitt, C. N., Erickson, D., Fall, R., Geron, C., Graedel, T., Harley, P., Klinger, L., Lerdau, M., Mckay, W. A., Pierce, T., Scholes, B., Steinbrecher, R., Tallamraju, R., Taylor, J., \& Zimmerman, P. (1995). A global model of natural volatile organic compound emissions. Journal of Geophysical Research, 100, 8873-8892. https://doi. org/10.1029/94JD02950

Guenther, A. B., Jiang, X., Heald, C. L., Sakulyanontvittaya, T., Duhl, T., Emmons, L. K., \& Wang, X. (2012). The Model of Emissions of Gases and Aerosols from Nature version 2.1 (MEGAN2.1): An extended and updated framework for modeling biogenic emissions. Geoscientific Model Development, 5(6), 1471-1492. https://doi. org/10.5194/gmd-5-1471-2012

Harris, I., Jones, P. D., Osborn, T. J., \& Lister, D. H. (2014). Updated highresolution grids of monthly climatic observations-The CRU TS3.10 Dataset. International Journal of Climatology, 34(3), 623-642. https://doi.org/10.1002/joc.3711

Hartley, A. J., MacBean, N., Georgievski, G., \& Bontemps, S. (2017). Uncertainty in plant functional type distributions and its impact on land surface models. Remote Sensing of Environment, 203, 71-89. https://doi.org/10.1016/j.rse.2017.07.037 
Hashimoto, H., Wang, W., Dungan, J. L., Li, S., Michaelis, A. R., Takenaka, H., Higuchi, A., Myneni, R. B., \& Nemani, R. R. (2021). New generation geostationary satellite observations support seasonality in greenness of the Amazon evergreen forests. Nature Communications, 12(1), 684. https://doi.org/10.1038/s41467-02120994-y

Hilker, T., Lyapustin, A. I., Tucker, C. J., Hall, F. G., Myneni, R. B., Wang, Y., Bi, J., Mendes de Moura, Y., \& Sellers, P. J. (2014). Vegetation dynamics and rainfall sensitivity of the Amazon. Proceedings of the National Academy of Sciences of the United States of America, 111(45), 16041-16046. https://doi.org/10.1073/pnas.1404870111

Jardine, K. J., Zorzanelli, R. F., Gimenez, B. O., Oliveira Piva, L. R. D., Teixeira, A., Fontes, C. G., Robles, E., Higuchi, N., Chambers, J. Q., \& Martin, S. T. (2020). Leaf isoprene and monoterpene emission distribution across hyperdominant tree genera in the Amazon basin. Phytochemistry, 175. https://doi.org/10.1016/j.phyto chem.2020.112366.

Joiner, J., Guanter, L., Lindstrot, R., Voigt, M., Vasilkov, A. P., Middleton, E. M., Huemmrich, K. F., Yoshida, Y., \& Frankenberg, C. (2013) Global monitoring of terrestrial chlorophyll fluorescence from moderate-spectral-resolution near-infrared satellite measurements: Methodology, simulations, and application to GOME-2. Atmospheric Measurement Techniques, 6(10), 2803-2823. https:// doi.org/10.5194/amt-6-2803-2013

Jung, M., Schwalm, C., Migliavacca, M., Walther, S., Camps-Valls, G., Koirala, S., Anthoni, P., Besnard, S., Bodesheim, P., Carvalhais, N., Chevallier, F., Gans, F., Goll, D. S., Haverd, V., Köhler, P., Ichii, K., Jain, A. K., Liu, J., Lombardozzi, D., ... Reichstein, M. (2020). Scaling carbon fluxes from eddy covariance sites to globe: Synthesis and evaluation of the FLUXCOM approach. Biogeosciences, 17(5), 13431365. https://doi.org/10.5194/bg-17-1343-2020

Lawlor, D. W., \& Tezara, W. (2009). Causes of decreased photosynthetic rate and metabolic capacity in water-deficient leaf cells: A critical evaluation of mechanisms and integration of processes. Annals of Botany, 103(4), 561-579. https://doi.org/10.1093/aob/mcn244

Le Quéré, C., Raupach, M. R., Canadell, J. G., Marland, G., Bopp, L., Ciais, P., Conway, T. J., Doney, S. C., Feely, R. A., Foster, P., Friedlingstein, P., Gurney, K., Houghton, R. A., House, J. I., Huntingford, C., Levy, P. E., Lomas, M. R., Majkut, J., Metzl, N., ... Woodward, F. I. (2009). Trends in the sources and sinks of carbon dioxide. Nature Geoscience, 2(12), 831-836. https://doi.org/10.1038/ngeo689

Lerdau, M. T., \& Throop, H. L. (1999). Isoprene emission and photosynthesis in a tropical forest canopy: Implications for model development. Ecological Applications, 9, 1109-1117.

Lewis, S. L., Brando, P. M., Phillips, O. L., van der Heijden, G. M. F., \& Nepstad, D. (2011). The 2010 Amazon drought. Science, 331(6017), 554. https://doi.org/10.1126/science.1200807

Liu, J., Bowman, K. W., Schimel, D. S., Parazoo, N. C., Jiang, Z., Lee, M., Bloom, A. A., Wunch, D., Frankenberg, C., Sun, Y., O'Dell, C. W., Gurney, K. R., Menemenlis, D., Gierach, M., Crisp, D., \& Eldering, A. (2017). Contrasting carbon cycle responses of the tropical continents to the 2015-2016 El Niño. Science, 358(6360), eaam5690. https://doi.org/10.1126/science.aam5690

Lloyd-Hughes, B. (2012). A spatio-temporal structure-based approach to drought characterisation. International Journal of Climatology, 32(3), 406-418. https://doi.org/10.1002/joc.2280

Marais, E. A., Jacob, D. J., Kurosu, T. P., Chance, K., Murphy, J. G., Reeves, C., Mills, G., Casadio, S., Millet, D. B., Barkley, M. P., Paulot, F., \& Mao, J. (2012). Isoprene emissions in Africa inferred from OMI observations of formaldehyde columns. Atmospheric Chemistry and Physics, 12(14), 6219-6235. https://doi.org/10.5194/acp-12-6219-2012

Marengo, J. A., Tomasella, J., Alves, L. M., Soares, W. R., \& Rodriguez, D. A. (2011). The drought of 2010 in the context of historical droughts in the Amazon region. Geophysical Research Letters, 38(12). https:// doi.org/10.1029/2011GL047436
Morfopoulos, C., Sperlich, D., Peñuelas, J., Filella, I., Llusià, J., Medlyn, B. E., Niinemets, Ü., Possell, M., Sun, Z. \& Prentice, I. C. (2014). A model of plant isoprene emission based on available reducing power captures responses to atmospheric $\mathrm{CO}_{2}$. New Phytologist, 203(1), 125-139. https://doi.org/10.1111/nph.12770

Morfopoulosl, C., Prentice, I. C., Keenan, T. F., Friedlingstein, P., Medlyn, B. E., Peñuelas, J., \& Possell, M. (2013). A unifying conceptual model for the environmental responses of isoprene emissions from plants. Annals of Botany, 112(7). https://doi.org/10.1093/aob/mct206

Niinemets, Ü., Monson, R. K., Arneth, A., Ciccioli, P., Kesselmeier, J. Kuhn, U., Noe, S. M., Peñuelas, J., \& Staudt, M. (2010). The leaf-level emission factor of volatile isoprenoids: Caveats, model algorithms, response shapes and scaling. Biogeosciences, 7, 1809-1832. https:// doi.org/10.5194/bg-7-1809-2010

Palmer, P. I., Jacob, D. J., Fiore, A. M., Martin, R. V., Chance, K., \& Kurosu, T. P. (2003). Mapping isoprene emissions over North America using formaldehyde column observations from space. Journal of Geophysical Research, 108(D6), 4180. https://doi. org/10.1029/2002JD002153

Pan, Y., Birdsey, R. A., Fang, J., Houghton, R., Kauppi, P. E., Kurz, W. A., Phillips, O. L., Shvidenko, A., Lewis, S. L., Canadell, J. G., Ciais, P., Jackson, R. B., Pacala, S. W., McGuire, A. D., Piao, S., Rautiainen, A., Sitch, S., \& Hayes, D. (2011). Persistent carbon sink in the world's forests. Science, 333(6045), 988-993. https://doi.org/10.1126/ science.1201609

Parveen, S., Rashid, M.-U., Inafuku, M., Iwasaki, H., \& Oku, H. (2019). Molecular regulatory mechanism of isoprene emission under shortterm drought stress in the tropical tree ficus septica. Tree Physiology, 39(3), 440-453. https://doi.org/10.1093/treephys/tpy123

Peñuelas, J., Marino, G., Llusia, J., Morfopoulos, C., Farré-Armengol, G., \& Filella, I. (2013). Photochemical reflectance index as an indirect estimator of foliar isoprenoid emissions at the ecosystem level. Nature Communications, 4(May), 2604. https://doi.org/10.1038/ ncomms 3604

Peñuelas, J., \& Staudt, M. (2010). BVOCs and global change. Trends in Plant Science, 15, 133-144. https://doi.org/10.1016/j.tplan ts.2009.12.005

Rasmijn, L. M., van der Schrier, G., Bintanja, R., Barkmeijer, J., Sterl, A., \& Hazeleger, W. (2018). Future equivalent of 2010 Russian heatwave intensified by weakening soil moisture constraints. Nature Climate Change, 8(5), 381-385. https://doi.org/10.1038/s4155 8-018-0114-0

Reichstein, M., Bahn, M., Ciais, P., Frank, D., Mahecha, M. D., Seneviratne, S. I., Zscheischler, J., Beer, C., Buchmann, N., Frank, D. C., Papale, D., Rammig, A., Smith, P., Thonicke, K., van der Velde, M., Vicca, S., Walz, A., \& Wattenbach, M. (2013). Climate extremes and the carbon cycle. Nature, 500, 287. https://doi.org/10.1038/nature12350

Rowland, L., da Costa, A. C. L., Galbraith, D. R., Oliveira, R. S., Binks, O. J., Oliveira, A. A. R., Pullen, A. M., Doughty, C. E., Metcalfe, D. B. Vasconcelos, S. S., Ferreira, L. V., Malhi, Y., Grace, J., Mencuccini, M., \& Meir, P. (2015). Death from drought in tropical forests is triggered by hydraulics not carbon starvation. Nature, 528(7580), 119122. https://doi.org/10.1038/nature15539

Saleska, S. R., Didan, K., Huete, A. R., \& da Rocha, H. R. (2007). Amazon forests green-up during 2005 drought. Science, 318(5850), 612. https://doi.org/10.1126/science.1146663

Seneviratne, S. I., Nicholls, N., Easterling, D., Goodess, C. M., Kanae, S., Kossin, J., Luo, Y., Marengo, J., Mclnnes, K., Rahimi, M., Reichstein, M., Sorteberg, A., Vera, C., Zhang, X., Alexander, L. V., Allen, S., Benito, G., Cavazos, T., Clague, J., ... Zwiers, F. W. (2012). Changes in climate extremes and their impacts on the natural physical environment. In Managing the risks of extreme events and disasters to advance climate change adaptation: Special report of the intergovernmental panel on climate change (pp. 109-230). https://doi. org/10.1017/CBO9781139177245.006 
Sharkey, T. D., \& Loreto, F. (1993). Water stress, temperature, and light effects on the capacity for isoprene emission and photosynthesis of kudzu leaves. Oecologia, 95, 328-333. https://doi.org/10.1007/ BF00320984

Sharkey, T. D., \& Monson, R. K. (2017). Isoprene research-60 years later, the biology is still enigmatic. Plant, Cell \& Environment, 40(9), 16711678. https://doi.org/10.1111/pce.12930

Sitch, S., Huntingford, C., Gedney, N., Levy, P. E., Lomas, M., Piao, S. L., Betts, R., Ciais, P., Cox, P., Friedlingstein, P., Jones, C. D., Prentice, I. C., \& Woodward, F. I. (2008). Evaluation of the terrestrial carbon cycle, future plant geography and climate-carbon cycle feedbacks using five Dynamic Global Vegetation Models (DGVMs). Global Change Biology, 14(9), 2015-2039. https://doi. org/10.1111/j.1365-2486.2008.01626.x

Smith, M. N., Taylor, T. C., van Haren, J., Rosolem, R., Restrepo-Coupe, N., Adams, J., Wu, J., de Oliveira, R. C., da Silva, R., de Araujo, A. C., de Camargo, P. B., Huxman, T. E., \& Saleska, S. R. (2020). Empirical evidence for resilience of tropical forest photosynthesis in a warmer world. Nature Plants, 6(October). https://doi.org/10.1038/ s41477-020-00780-2

Stavrakou, T., Müller, J.-F., Bauwens, M., De Smedt, I., Van Roozendael, M., \& Guenther, A. (2018). Impact of short-term climate variability on volatile organic compounds emissions assessed using OMI satellite formaldehyde observations. Geophysical Research Letters, 45(16), 8681-8689. https://doi.org/10.1029/2018GL078676

Stavrakou, T., Müller, J.-F., De Smedt, I., Van Roozendael, M., van der Werf, G. R., Giglio, L., \& Guenther, A. (2009). Evaluating the performance of pyrogenic and biogenic emission inventories against one decade of space-based formaldehyde columns. Atmospheric Chemistry and Physics, 9, 1037-1060. https://doi.org/10.5194/ acp-9-1037-2009

Taylor, T. C., McMahon, S. M., Smith, M. N., Boyle, B., Violle, C., Haren, J., Simova, I., Meir, P., Ferreira, L. V., Camargo, P. B., Costa, A. C. L., Enquist, B. J., \& Saleska, S. R. (2018). Isoprene emission structures tropical tree biogeography and community assembly responses to climate. New Phytologist, 220(2), 435-446. https://doi. org/10.1111/nph.15304

Taylor, T. C., Smith, M. N., Slot, M., \& Feeley, K. J. (2019). The capacity to emit isoprene differentiates the photosynthetic temperature responses of tropical plant species. Plant, Cell \& Environment, 42(8), 2448-2457. https://doi.org/10.1111/pce.13564

Tingey, D. T., Evans, R., \& Gumpertz, M. (1981). Effects of environmental conditions on isoprene emission from live oak. Planta, 152, 565570. https://doi.org/10.1007/BF00380829

Tramontana, G., Jung, M., Schwalm, C. R., Ichii, K., Camps-Valls, G., Ráduly, B., Markus Reichstein, M., Arain, A., Cescatti, A., Kiely, G., Merbold, L., Serrano-Ortiz, P., Sickert, S., Wolf, S. \& Papale, D. (2016). Predicting carbon dioxide and energy fluxes across global FLUXNET sites with regression algorithms. Biogeosciences, 13(14), 4291-4313. https://doi.org/10.5194/bg-13-4291-2016

Trenberth, K. E., \& Fasullo, J. T. (2012). Climate extremes and climate change: The Russian heat wave and other climate extremes of 2010.
Journal of Geophysical Research: Atmospheres, 117(D17). https://doi. org/10.1029/2012JD018020

van der Werf, G. R., Randerson, J. T., Giglio, L., van Leeuwen, T. T., Chen, Y., Rogers, B. M., Mu, M., \& van Marle, M. J. E., Morton, D. C. Collatz, G. J., Yokelson, R. J., \& Kasibhatla, P. S. (2017). Global fire emissions estimates during 1997-2016. Earth System Science Data, 9(2), 697-720. https://doi.org/10.5194/essd-9-697-2017

Wan, Z. (2014). New refinements and validation of the collection-6 MODIS land-surface temperature/emissivity product. Remote Sensing of Environment, 140, 36-45. https://doi.org/10.1016/j. rse.2013.08.027

Wells, K. C., Millet, D. B., Payne, V. H., Deventer, M. J., Bates, K. H., de Gouw, J. A., Graus, M., Warneke, C., Wisthaler, A., \& Fuentes, J. D. (2020). Satellite isoprene retrievals constrain emissions and atmospheric oxidation. Nature, 585(7824), 225-233. https://doi. org/10.1038/s41586-020-2664-3

Wolter, K., \& Timlin, M. S. (2011). El Niño/Southern Oscillation behaviour since 1871 as diagnosed in an extended multivariate ENSO index (MEl.ext). International Journal of Climatology, 31(7), 1074-1087. https://doi.org/10.1002/joc.2336

Zhu, Z., Bi, J., Pan, Y., Ganguly, S., Anav, A., Xu, L., Samanta, A., Piao, S., Nemani, R., \& Myneni, R. (2013). Global data sets of vegetation leaf area index (LAI)3g and fraction of photosynthetically active radiation (FPAR)3g derived from global inventory modeling and mapping studies (GIMMS) normalized difference vegetation index (NDVI3g) for the period 1981 to 2011. Remote Sensing, 5(2), 927-948. https:// doi.org/10.3390/rs5020927

Zscheischler, J., Mahecha, M. D., Harmeling, S., \& Reichstein, M. (2013). Detection and attribution of large spatiotemporal extreme events in Earth observation data. Ecological Informatics, 15, 66-73. https:// doi.org/10.1016/j.ecoinf.2013.03.004

Zscheischler, J., Mahecha, M. D., von Buttlar, J., Harmeling, S., Jung, M., Rammig, A., Randerson, J. T., Schölkopf, B., Seneviratne, S. I., Tomelleri, E., Zaehle, S., \& Reichstein, M. (2014). A few extreme events dominate global interannual variability in gross primary production. Environmental Research Letters, 9(3), 35001. https://doi.or g/10.1088/1748-9326/9/3/035001

\section{SUPPORTING INFORMATION}

Additional Supporting Information may be found in the online version of the article at the publisher's website.

How to cite this article: Morfopoulos C, Müller J-F, Stavrakou

$\mathrm{T}$, et al. Vegetation responses to climate extremes recorded by remotely sensed atmospheric formaldehyde. Glob Change Biol. 2022;28:1809-1822. https://doi.org/10.1111/gcb.15880 